\title{
The hanR/hanl quorum-sensing system of Halomonas anticariensis, a moderately halophilic bacterium
}

Correspondence

Inmaculada Llamas

illamas@ugr.es

Received 21 June 2011

Revised 11 October 2011

Accepted 13 October 2011

\section{Ali Tahrioui, Emilia Quesada and Inmaculada Llamas}

Microbial Exopolysaccharide Research Group, Department of Microbiology, Faculty of Pharmacy, Cartuja Campus, University of Granada, 18071 Granada, Spain

\begin{abstract}
Quorum sensing is a cell density-dependent gene expression mechanism found in many Gramnegative bacteria which involves the production of signal molecules such as $N$-acylhomoserine lactones (AHLs). One significant group of micro-organisms in which quorum sensing has not been previously studied, however, are the moderate halophiles. We describe here the results of our studies of the quorum-sensing system in Halomonas anticariensis $\mathrm{FP}^{\mathrm{T}} 5^{\mathrm{T}}$, which is composed of luxR/luxl homologues: hanR (the putative transcriptional regulator gene) and han/ (the autoinducer synthase gene). To understand how the hanR/han/ system is organized and regulated we conducted RT-PCR and quantitative real-time PCR assays. Transcriptional analysis indicated that the hanR and hanl genes are on the same transcript and that their transcription is growth phase-dependent. Hanl seems to be the only autoinducer synthase responsible for the synthesis of AHLs by the bacterium, since the inactivation of han/ resulted in the complete loss of its AHLs. We also found that the hanl gene appears to be transcribed from its own promoter and that its expression does not depend upon HanR. This finding was supported by the fact that the FP35hanR mutant showed AHL-producing activity and han/ expression similar to that of the wildtype strain, the latter being measured by RT-PCR. Moreover, hanR is expressed from its own promoter and appears to be independent of the AHL signalling molecules produced by Hanl.
\end{abstract}

\section{INTRODUCTION}

Over the past few years it has become increasingly evident that numerous bacteria can establish cell-to-cell communication within their communities by producing small signal molecules that either diffuse freely across the cell membranes or are actively transported out of the cell. These signals, known as autoinducers, control gene expression in response to bacterial cell density in a process called quorum sensing (reviewed by González \& Marketon, 2003; Ng \& Bassler, 2009; Parker \& Sperandio, 2009).

The most thoroughly characterized Gram-negative, bacterial, intraspecific autoinducers are $\mathrm{N}$-acylhomoserine lactones (AHLs), which have been reported to be synthesized by a member of the LuxI protein family in over 70 genera belonging to the phylum Proteobacteria. AHL molecules

Abbreviations: AHL, N-acylhomoserine lactone; $\mathrm{C}_{4}-\mathrm{HL}, \mathrm{N}$-butanoyl homoserine lactone; $\mathrm{C}_{6}-\mathrm{HL}, \mathrm{N}$-hexanoyl homoserine lactone; $\mathrm{C}_{8}-\mathrm{HL}$, $\mathrm{N}$-octanoyl homoserine lactone; $\mathrm{C}_{12}-\mathrm{HL}, \mathrm{N}$-dodecanoyl homoserine lactone; 3-oxo- $\mathrm{C}_{6}-\mathrm{HL}, \quad \mathrm{N}$-( $\beta$-ketocaproyl)-L-homoserine lactone; RTqPCR, reverse transcription quantitative real-time PCR.

The GenBank/EMBL/DDBJ accession number for the hanR-han/ DNA sequence of $H$. anticariensis is HM236058.

Three supplementary figures and two supplementary tables are available with the online version of this paper. differ in the length and substitution of their respective acyl side chains, conferring upon them signal specificity. As the density of the population increases AHL molecules accumulate in the growth medium, and on reaching a critical concentration threshold they bind and activate an AHL receptor protein belonging to the LuxR family of transcriptional regulators. The activated LuxR/AHL complex then binds to a specific palindromic sequence on the DNA, known as the 'lux box', located upstream of the genes regulated by quorum sensing. This results in the activation or repression of target genes, including in many cases the activation of the autoinducer synthase, which leads in turn to the production of more AHLs and consequently a positive feedback loop (Eberhard et al., 1991; Fuqua et al., 1994).

This phenomenon has usually been found in bacteria that live in pathogenic or symbiotic associations in which quorum-sensing systems regulate genes involved in the expression of virulence factors and exoenzymes (de Kievit \& Iglewski, 2000; Song et al., 2005; von Bodman et al., 2003), conjugal DNA transfer and plasmid copy number control (Farrand, 1998; Fuqua et al., 2001, 1994; Marketon \& González, 2002), production of and susceptibility to antibiotics (Horng et al., 2002; McClean et al., 1997; Pumbwe et al., 2008; Van Houdt et al., 2007), biofilm formation (Davies et al., 1998; McNab et al., 2003; Niu 
et al., 2008) and exopolysaccharide production (Marketon et al., 2003; von Bodman et al., 1998).

In addition to AHLs, other quorum-sensing autoinducer molecules recently identified in Gram-negative bacteria are autoinducer 2 (AI-2) (Chen et al., 2002), which has been described as a global signal molecule for interspecific communication, 2-alkyl-4-quinolones (AQs), such as PQS in Pseudomonas (Diggle et al., 2007), long-chain fatty acids, such as the 'diffusible signal factor' (DSF) in Xanthomonas campestris (Wang et al., 2004), p-coumaroyl-HSL in Rhodopseudomonas palustris (Schaefer et al., 2008) and others (González \& Keshavan, 2006; Ng \& Bassler, 2009).

It has been reported that in complex environments bacterial signalling does not accumulate at a constant rate (Boyer \& Wisniewski-Dyé, 2009). The diffusion and perception of AHLs in and around cells can be influenced by abiotic environmental factors such as $\mathrm{pH}$, temperature and medium composition, and by other members of the bacterial community in a process known as 'quorum quenching' (Defoirdt et al., 2008; Taga \& Bassler, 2003). A variety of bacterial biosensor strains have been constructed to detect autoinducer molecules (Llamas et al., 2004; McClean et al., 1997; Shaw et al., 1997; Winson et al., 1998). These strains do not produce any AHL signal molecules but can detect exogenous AHLs by the activation of a reporter gene such as lacZ or lux or, in Chromobacterium violaceum, by the production or inhibition of a purple pigment. The use of these biosensors in a previous study led us to observe that the exopolysaccharide-producing Halomonas anticariensis $\mathrm{FP} 35^{\mathrm{T}}$ synthesizes quorum-sensing molecules in a growth phase-dependent manner and that its maximum activity is reached by the end of the exponential phase. In addition, using electrospray ionization MS (ESI MS/MS), we have identified some of the AHL molecular structures in this bacterium, such as $\mathrm{N}$-butanoyl homoserine lactone $\left(\mathrm{C}_{4}\right.$ $\mathrm{HL}), \mathrm{N}$-hexanoyl homoserine lactone $\left(\mathrm{C}_{6}-\mathrm{HL}\right), \mathrm{N}$-octanoyl homoserine lactone $\left(\mathrm{C}_{8}-\mathrm{HL}\right)$ and $\mathrm{N}$-dodecanoyl homoserine lactone $\left(\mathrm{C}_{12}-\mathrm{HL}\right)$ (Llamas et al., 2005).

Cell density-dependent gene regulation has not been studied to date in extreme environments such as those inhabited by Halomonas species. The genus Halomonas currently comprises more than 70 species of halophilic bacteria, most of which have been isolated from saline environments such as salterns, saline soils, seawater and marshes (Euzéby, 2010). Its members are extremely versatile from the ecological, physiological and metabolic point of view. The interest in Halomonas species has centred on their ability to degrade aromatic compounds and produce compatible solutes, halophilic enzymes and exopolysaccharides with potential applications in biotechnology (Sutherland, 2002).

In this study we have genetically characterized the quorumsensing system involved in the production of AHLs in $H$. anticariensis $\mathrm{FP} 35^{\mathrm{T}}$, which is composed of a putative transcriptional regulator HanR (LuxR homologue) and an AHL synthase HanI (LuxI homologue). Gene expression analysis demonstrates that the hanR/hanI genes are organized in the same operon and that their expression is cell density-dependent. The expression of hanR appears to be independent of the AHL signalling molecules produced by HanI, an unusual characteristic compared with other LuxRI-like systems already characterized (González \& Marketon, 2003).

\section{METHODS}

Bacterial strains, plasmids, media and culture conditions. The bacterial strains and plasmids used are listed in Table 1. $H$. anticariensis strains were routinely cultured at $32{ }^{\circ} \mathrm{C}$ in SWYE (Nieto et al., 1989) or MY medium (Moraine \& Rogovin, 1966) modified with a balanced mixture of sea salts (Rodríguez-Valera et al., 1981). Escherichia coli strains were grown at $37{ }^{\circ} \mathrm{C}$ in LB medium (Sambrook \& Russell, 2001). Antibiotics were added at the following final concentrations: rifampicin, $50 \mu \mathrm{g} \mathrm{ml}^{-1}$; kanamycin, $50 \mu \mathrm{g} \mathrm{ml}^{-1}$; gentamicin, $25 \mu \mathrm{g} \mathrm{ml}^{-1}$; tetracycline, $15 \mu \mathrm{g} \mathrm{ml}^{-1}$; and ampicillin, $100 \mu \mathrm{g} \mathrm{ml}^{-1}$. Agrobacterium tumefaciens NTL4 (pZLR4) was cultured at $30{ }^{\circ} \mathrm{C}$ in $\mathrm{LB}$ medium supplemented with $2.5 \mathrm{mM} \mathrm{CaCl}_{2}$ and $2.5 \mathrm{mM} \mathrm{MgSO}_{4}$ (LB/MC) and in MGM minimal medium (per litre: $11 \mathrm{~g} \mathrm{Na} \mathrm{NPO}_{4}, 3 \mathrm{~g} \mathrm{KH}_{2} \mathrm{PO}_{4}, 0.5 \mathrm{~g} \mathrm{NaCl}, 1 \mathrm{~g}$ glutamate, $10 \mathrm{~g}$ mannitol, $1 \mathrm{mg}$ biotin, $\left.27.8 \mathrm{mg} \mathrm{CaCl}_{2}, 246 \mathrm{mg} \mathrm{MgSO}_{4}\right)$ containing $50 \mu \mathrm{g}$ gentamicin $\mathrm{ml}^{-1}$. C. violaceum $\mathrm{CV} 026$ was grown at $30{ }^{\circ} \mathrm{C}$ in LB medium.

Transposon mutagenesis and isolation of the FP35-11I (FP35:: hanR:: mini-Tn5 Km2) mutant. Transposon mutagenesis was carried out via conjugation by biparental mating, as described in a previous publication (Llamas et al., 2000). The donor strain was $E$. coli S17-1 $\lambda$ pir, harbouring the suicide vector pUT mini-Tn5 Km2 (de Lorenzo et al., 1990). The recipient strain was H. anticariensis FP35-R, a spontaneous rifampicin-resistant mutant of $H$. anticariensis $\mathrm{FP} 35^{\mathrm{T}}$. The transconjugants were isolated on SWYE medium containing $2 \%$ $(\mathrm{w} / \mathrm{v})$ salts, rifampicin $\left(50 \mu \mathrm{g} \mathrm{ml}^{-1}\right)$ and kanamycin $\left(50 \mu \mathrm{g} \mathrm{ml}^{-1}\right)$. Selected clones were replicated onto both the same isolating medium and trypticase soy agar (TSA) (per litre: $15 \mathrm{~g}$ trypticase peptone, $5 \mathrm{~g}$ phytone peptones, $5 \mathrm{~g} \mathrm{NaCl}, 15 \mathrm{~g}$ agar) and incubated overnight at $32{ }^{\circ} \mathrm{C}$. The halophilic clones that did not grow in TSA medium due to its low salt content were then streaked onto LB/MC or MGM media, where the indicator strains [C. violaceum CV026 or A. tumefaciens NTL4 (pZLR4)] had been previously streaked in order to isolate AHLdeficient strains. They were incubated overnight at $32{ }^{\circ} \mathrm{C}$ to allow the indicator organisms to grow and surround the clone growths with either purple or blue haloes.

Cloning of the hanRl genes. To isolate the DNA fragment carrying the mini-Tn5 insertion, which encodes the kanamycin-resistance gene, genomic DNA from $H$. anticariensis FP35-11I was completely digested with enzymes that do not cleave within the minitransposon region. DNA fragments were separated on an agarose gel and transferred onto a nylon filter by standard techniques (Sambrook \& Russell, 2001). Fragments containing the mini-Tn5 Km2 insertion were analysed by Southern hybridization using a digoxigenin DNA labelling and detection kit (Boehringer Mannheim) as described in previous publications (Llamas et al., 1997, 2003). Chromosomal DNA fragments digested with PstI were selected and ligated into pGEM-T to create pP11I. The cloned fragments were sequenced directly by primer walking using a BigDye Terminator Cycle Sequencing kit in an ABI 3100 DNA sequencer (Applied Biosystems). The genomic sequence located upstream of the known nucleotide sequence was obtained by inverse PCR (Ochman et al., 1988; Llamas et al., 2003). One plasmid, pBFP35, was isolated and sequenced. The DNA 
Table 1. Bacterial strains and plasmids used in this study

Abbreviations: $\mathrm{Ap}^{\mathrm{r}}$, ampicillin resistance; $\mathrm{Gm}^{\mathrm{r}}$, gentamicin resistance; $\mathrm{Km}^{\mathrm{r}}$, kanamycin resistance; Rif ${ }^{\mathrm{r}}$, rifampicin resistance; $\mathrm{Tc}^{\mathrm{r}}$, tetracycline resistance.

\begin{tabular}{|c|c|c|}
\hline Strain or plasmid & Genotype or description & Reference or source \\
\hline \multicolumn{3}{|l|}{ H. anticariensis strains: } \\
\hline $\mathrm{FP} 35^{\mathrm{T}}\left(=\right.$ CECT $\left.5854^{\mathrm{T}}\right)$ & Wild-type isolate, mucoid & Martínez-Cánovas et al. (2004) \\
\hline FP35-R & Spontaneous rifampicin-resistant mutant of FP35, Rif & This work \\
\hline FP35-11I & FP35-R containing hanR:: mini-Tn5 Km2, Rif $^{\mathrm{r}}, \mathrm{Km}^{\mathrm{r}}$ & This work \\
\hline FP35hanI & FP35-R containing hanI: : lacZ, $\operatorname{Rif}^{\mathrm{r}}, \mathrm{Km}^{\mathrm{r}}$ & This work \\
\hline FP35hanR & FP35-R containing hanR: : lacZ, Rif $^{\mathrm{r}}, \mathrm{Km}^{\mathrm{r}}$ & This work \\
\hline FP35(pMP220) & FP35-R containing pMP220, Rif ${ }^{\mathrm{r}}, \mathrm{Tc}^{\mathrm{r}}$ & This work \\
\hline FP35(pMP-phanR) & FP35-R containing pMP-phanR, $\operatorname{Rif}^{\mathrm{r}}, \mathrm{Tc}^{\mathrm{r}}$ & This work \\
\hline FP35(pMP-phanI) & FP35-R containing pMP-phanR, $\operatorname{Rif}^{\mathrm{r}}, \mathrm{Tc}^{\mathrm{r}}$ & This work \\
\hline FP35-11I(pJN-HanR) & FP35-R containing hanR:: mini-Tn5 $\mathrm{Km} 2$ and pJN-HanR, Rif ${ }^{\mathrm{r}}, \mathrm{Km}^{\mathrm{r}}, \mathrm{Gm}^{\mathrm{r}}$ & This work \\
\hline FP35hanI(pJN-HanI) & FP35-R containing hanI: : lacZ and pJN-HanI, Rif ${ }^{\mathrm{r}}, \mathrm{Km}^{\mathrm{r}}, \mathrm{Gm}^{\mathrm{r}}$ & This work \\
\hline A. tumefaciens NTL4(pZLR4) & NT1 derivative carrying a $\operatorname{tra} G:$ : lac $Z$ reporter fusion, $\mathrm{Gm}^{\mathrm{r}}$ & Shaw et al. (1997) \\
\hline C. violaceum $\mathrm{CV} 026$ & CV017 derivative containing cviI::Tn $5 x y l E, \mathrm{Km}^{\mathrm{r}}$ & McClean et al. (1997) \\
\hline \multicolumn{3}{|l|}{ E. coli strains: } \\
\hline $\mathrm{DH} 5 \alpha$ & $\begin{array}{l}\mathrm{F}^{-} \phi 80 d \text { lacZAM15 } \Delta(\text { lacZY-argF }) \mathrm{U} 169 \text { deoR recA1 endA1 hsdR17 }\left(\mathrm{r}_{\mathrm{K}}^{-} \mathrm{m}_{\mathrm{K}}^{-}\right) \\
\text {supE44 } \lambda^{-} \text {thi-1 girA96 relA1 }\end{array}$ & Laboratory collection \\
\hline S17-1 $\lambda$ pir & RK2 tra regulon, pir, host for pir-dependent plasmids & Miller \& Mekalanos (1988) \\
\hline \multicolumn{3}{|l|}{ Plasmids: } \\
\hline pGEM-T & High-copy-number cloning vector, $\mathrm{Ap}^{\mathrm{r}}$, bla, lacZ & Promega \\
\hline pUT mini-Tn $5 \mathrm{Km} 2$ & $\mathrm{Ap}^{\mathrm{r}}, \mathrm{Km}^{\mathrm{r}}$, ori $\mathrm{R} 6 \mathrm{~K}$, oriT $\mathrm{RP} 4$ & de Lorenzo et al. (1990) \\
\hline $\mathrm{pP} 11 \mathrm{I}$ & pGEM-T with a $5 \mathrm{~kb}$ PstI fragment carrying mini-Tn5 insertion, $\mathrm{Ap}^{\mathrm{r}}, \mathrm{Km}^{\mathrm{r}}$ & This work \\
\hline pBFP35 & $\begin{array}{l}\text { pGEM-T with a } 1.6 \mathrm{~kb} \text { inverse PCR product amplified from a } 2.2 \mathrm{~kb} \\
\text { fragment from strain FP35 genome, } \mathrm{Ap}^{\mathrm{r}}\end{array}$ & This work \\
\hline pVIK112 & lacZY for disruption and transcriptional fusion, $\mathrm{Km}^{\mathrm{r}}$ & Kalogeraki \& Winans (1997) \\
\hline pVIKHanI & pVIK112 containing an internal hanI fragment, transcriptional fusion, $\mathrm{Km}^{\mathrm{r}}$ & This work \\
\hline pVIKHanR & pVIK112 containing an internal han $R$ fragment, transcriptional fusion, $\mathrm{Km}^{\mathrm{r}}$ & This work \\
\hline pMP220 & Promoter-probe vector, 'lacZ; IncP; $\mathrm{Tc}^{\mathrm{r}}$ & Spaink et al. (1987) \\
\hline pMP-phanI & pMP220 containing hanI promoter & This work \\
\hline pMP-phanR & pMP220 containing han $R$ promoter & This work \\
\hline pJN105 & araC- $\mathrm{P}_{\mathrm{BAD}}$ cassette cloned in pBBR1MCS5 & Newman \& Fuqua (1999) \\
\hline pJN-HanI & pJN105 containing intact hanI, $\mathrm{Gm}^{\mathrm{r}}$ & This work \\
\hline pJN-HanR & pJN105 containing intact hanR, $\mathrm{Gm}^{\mathrm{r}}$ & This work \\
\hline
\end{tabular}

sequences thus obtained were analysed using a BLAST search of the GenBank database (National Center for Biotechnology Information; NCBI; http://www.ncbi.nlm.nih.gov). Promoter regions were predicted with the BPROM software (Softberry; http://linuxl.softberry. com/berry.phtml). The conserved domains of the LuxR-type transcriptional regulator were identified using the SMART program (Letunic et al., 2006).

DNA manipulations. All molecular techniques were performed using standard protocols (Sambrook \& Russell, 2001). The primers used in this study are listed in Supplementary Table S1.

Construction of the hanR and hanl gene mutations. An internal fragment lacking both the $5^{\prime}$ and $3^{\prime}$ ends of the hanR and hanI genes was cloned separately into the suicide plasmid pVIK112, containing the promoterless lacZ gene. Chromosomal gene disruptions were then effected in a single step by Campbell-type integration of the entire plasmid by homologous recombination (Kalogeraki \& Winans, 1997).

Internal segments of 301 and $356 \mathrm{bp}$ of the hanR and hanI genes, respectively, were amplified from $H$. anticariensis $\mathrm{FP}^{\mathrm{T}}$ chromosomal DNA by using the primers hanRsub-EcoRI-F and hanRsub$X b a I-R$ for hanR, and hanIsub-EcoRI-F and hanIsub-XbaI-R for hanI, which contain EcoRI and XbaI restriction sites (underlined) at their respective $5^{\prime}$ ends (Supplementary Table S1). PCR entailed 30 cycles of $30 \mathrm{~s}$ at $95{ }^{\circ} \mathrm{C}, 30 \mathrm{~s}$ at $66^{\circ} \mathrm{C}$ and $30 \mathrm{~s}$ at $72{ }^{\circ} \mathrm{C}$. The PCR fragments were purified, cloned into pGEM-T, and digested with $E c o$ RI and XbaI. The purified fragments were then cloned into the suicide plasmid pVIK112. The resulting plasmids, pVIKHanR and pVIKHanI, were subsequently transformed separately into E. coli S171 ipir and transferred into a rifampicin-resistant FP35 derivative (FP35-R) by biparental mating, where the promoterless reporter lac Z gene simultaneously disrupted and created fusions to the hanR and hanI genes by single recombination. The $H$. anticariensis transconjugants, FP35hanI and FP35hanR, were selected by plating them on SWYE medium containing $2 \%(\mathrm{w} / \mathrm{v})$ salts, rifampicin $\left(50 \mu \mathrm{g} \mathrm{ml}^{-1}\right)$ and kanamycin $\left(50 \mu \mathrm{g} \mathrm{ml}^{-1}\right)$ (Kalogeraki \& Winans, 1997; Llamas et al., 2004) (Table 1).

Cloning of the hanR and hanl genes in the expression vector pJN105. The ORFs of hanR and hanI were amplified from $H$. anticariensis $\mathrm{FP} 35^{\mathrm{T}}$ chromosomal DNA by using the primers hanREcoRI-F and hanR-XbaI-R, and hanI-EcoRI-F and hanI-XbaI-R, respectively, which contain $E c o$ RI and $X b a I$ restriction sites at their respective $5^{\prime}$ ends (Supplementary Table S1). PCR entailed 30 cycles 
of $30 \mathrm{~s}$ at $95{ }^{\circ} \mathrm{C}, 30 \mathrm{~s}$ at $60{ }^{\circ} \mathrm{C}$ and $1 \mathrm{~min}$ at $72{ }^{\circ} \mathrm{C}$. The PCR fragment was purified, digested with EcoRI and $\mathrm{XbaI}$, and cloned into the broad-host-range expression vector pJN105, which carries the Larabinose-inducible E. coli araBAD promoter and the $\operatorname{araC}$ regulator ( $\left.\operatorname{araC}-\mathrm{P}_{\mathrm{BAD}}\right)$ (Newman \& Fuqua, 1999) to create pJN-HanR and pJNHanI. The pJN-HanR and pJN-HanI plasmids were then transformed separately into E. coli S17-1 $\lambda$ pir and transferred by biparental mating into the AHL-deficient strains FP35-11I and FP35hanI, respectively, to be used in complementation analysis. To confirm whether AHL production was restored in strains FP35-11I (pJN-HanR) and FP35hanI (pJN-HanI), signal molecules were extracted and analysed following the technique described in previous studies (Llamas et al., 2004, 2005; Marketon et al., 2002). All constructs were confirmed by PCR.

RNA extraction and RT-PCR assays. Total bacterial RNA was isolated using the RNA II Nucleospin kit (Macherey-Nagel), followed by rigorous treatment with Turbo DNA-free RNase (Ambion) according to the manufacturer's protocol. All RNA samples were visualized on the gel and the concentrations were measured with a NanoDrop ND-2000c spectrophotometer (Thermo Scientific). RT-PCR was conducted with $0.05-0.5 \mu \mathrm{g}$ total RNA at a final volume of $50 \mu \mathrm{l}$ using the SuperScript III One-Step RT-PCR System with PlatinumTaq according to the manufacturer's instructions (Invitrogen). cDNA was synthesized at $55{ }^{\circ} \mathrm{C}$ for $30 \mathrm{~min}$. Denaturation was performed for $2 \mathrm{~min}$ at $94{ }^{\circ} \mathrm{C}$, followed by 35 cycles of PCR, as suggested by the manufacturer. A final elongation step was conducted at $68{ }^{\circ} \mathrm{C}$ for $7 \mathrm{~min}$. The annealing temperature was calculated for each reaction on the basis of the melting temperatures of the pairs of primers used (Supplementary Table S1). Positive and negative controls were included in all the assays. $16 \mathrm{~S}$ rRNA was used as a control for normalization. RTPCR products were visualized by electrophoresis.

Reverse transcription quantitative real-time PCR analysis (RTqPCR). Total RNA from bacterial cultures growing at the early exponential and stationary phases $\left(\mathrm{OD}_{600}\right.$ values of 0.4 and 1.4, respectively) was extracted as described above. All RNA samples were prepared from two independent cultures. RNA preparations $(1 \mu \mathrm{g})$ treated with Turbo DNA-free RNase (Ambion) were reversetranscribed using the iScript cDNA Synthesis kit (Bio-Rad). RTqPCR was done with an iCycler iQ system (Bio-Rad). Each reaction mixture contained $1 \mu \mathrm{l}$ of the target cDNA or a dilution $(1: 10000$, for amplification of the 16S rRNA gene), $100 \mathrm{nM}$ of each of the forward and reverse primers, $10 \mu \mathrm{l} 2 \times$ iQ SYBR Green Supermix (Bio-Rad) and nuclease-free water to a final volume of $20 \mu \mathrm{l}$. All reactions were repeated in triplicate. PCRs were also carried out with the RNA samples untreated with reverse transcriptase to confirm the absence of contaminating genomic DNA. The oligonucleotide sequences used for RT-qPCR analysis are listed in Supplementary Table S1. The amplification conditions consisted of an initial $3 \mathrm{~min}$ denaturation step at $95{ }^{\circ} \mathrm{C}$, followed by 40 cycles each of denaturation at $95{ }^{\circ} \mathrm{C}$ for $10 \mathrm{~s}$, annealing at $62{ }^{\circ} \mathrm{C}$ for $30 \mathrm{~s}$, and extension at $72{ }^{\circ} \mathrm{C}$ for $30 \mathrm{~s}$. Negative controls without cDNA for each primer set were included in each run. At the end of the real-time PCR cycles, a melting curve was generated and analysed to confirm product specificity. For all genes, melting-curve analysis showed clear melting peaks without non-specific products or artefacts. Standard curves were obtained using recombinant plasmids containing a fragment of the gene of interest. The relative expression of each gene was normalized to that of $16 \mathrm{~S}$ rRNA and evaluated during the early exponential phase versus the stationary phase using the Relative Expression Software Tool (REST2009) (Pfaffl et al., 2002).

Analysis of hanR and hanl promoter activity. The promoter regions of the hanR and hanI genes (phanR and phanI respectively) were amplified by PCR with primers incorporating BglII and XbaI linkers for phanR, and EcoRI and XbaI linkers for phanI, respectively
(Supplementary Table S1). The promoter region of each gene was fused to the lac $Z$ gene in the promoterless low-copy-number pMP220 vector (Spaink et al., 1987). Upon amplification, DNA was cloned into the pGEM-T vector, digested with the appropriate restriction enzymes, and ligated to pMP220 for the construction of pMP-phanR and pMP-phanI. The constructions were confirmed by DNA sequencing. The pMP220, pMP-pHanR and pMP-pHanI plasmids were then transformed separately into E. coli S17-1 $\lambda$ pir and transferred by biparental mating into $H$. anticariensis FP35-R (Table $1)$. Promoter activity was analysed by measuring $\beta$-galactosidase activity (Miller, 1972).

\section{Extraction, detection and TLC analysis of crude AHL extracts.} AHL molecules were extracted following the technique described in our previous studies (Llamas et al., 2004; Marketon et al., 2002). To detect AHLs, an overnight culture of the AHL indicator strain $C$. violaceum CV026 was diluted 1:100 in $5 \mathrm{ml} \mathrm{LB}$ medium and poured onto LB agar. Once the plates were dried, paper disks $5 \mathrm{~mm}$ in diameter were placed on an agar plate and the AHL samples were applied. The assay plates were incubated overnight at $32{ }^{\circ} \mathrm{C}$ and the appearance of pigment around the filter was determined. To characterize the AHLs, the samples were subjected to analytical and preparative TLC. AHL samples and standards were spotted onto a TLC plate and developed with $70 \%(\mathrm{v} / \mathrm{v})$ methanol in water. The plate was air-dried and overlaid with top agar containing the $A$. tumefaciens NTL4 (pZLR4) indicator strain before being incubated at $32{ }^{\circ} \mathrm{C}$ (Llamas et al., 2005).

AHL standards were obtained from Sigma $[N$-( $\beta$-ketocaproyl $)$-Lhomoserine lactone (3-oxo- $\left.\left.\mathrm{C}_{6}-\mathrm{HL}\right)\right]$ and Fluka $\left(\mathrm{C}_{6}-\mathrm{HL}\right.$ and $\left.\mathrm{C}_{8}-\mathrm{HL}\right)$.

\section{RESULTS AND DISCUSSION}

\section{Isolation and characterization of the AHL- deficient strain FP35-11I}

In a previous paper we reported that the exopolysaccharide-producing $H$. anticariensis $\mathrm{FP} 35^{\mathrm{T}}$ synthesizes at least four AHLs $\left(\mathrm{C}_{4}-\mathrm{HL}, \mathrm{C}_{6}-\mathrm{HL}, \mathrm{C}_{8}-\mathrm{HL}\right.$ and $\mathrm{C}_{12}-\mathrm{HL}$ ) (Llamas et al., 2005). In an effort to identify the genes involved in their production, one of the four partially AHL-deficient $H$. anticariensis clones obtained by transposon mutagenesis, the FP35-11I mutant, was chosen for this study because it activated the two indicator strains to a lesser extent than did the wild-type strain. To further confirm the lower AHL production exhibited by this mutant, $5 \mathrm{ml}$ culture extracts from both the $H$. anticariensis wild-type and FP35-11I mutant strains were analysed on an agar plate and by TLC. Analysis with the CV026 and NTL4 (pZLR4) indicator organisms revealed that the FP35-11I mutant (Fig. 1a, panel 2 and b, lane 2) produced lower levels of AHLs than the wild-type strain (Fig. 1a, panel 1 and $\mathrm{b}$, lane 1 ).

\section{Cloning and sequencing of IuxR and IuxI homologues from $H$. anticariensis $\mathrm{FP}^{\mathrm{T}}{ }^{\mathrm{T}}$}

The nucleotide sequences of the chromosomal DNA in the two recombinant plasmids, pP11I and pBFP35 (see Methods), revealed the presence of two complete ORFs (Fig. 2a). The transposon insertion site within the FP35-11I genome was located after base pair 394 from the translation 
(a)

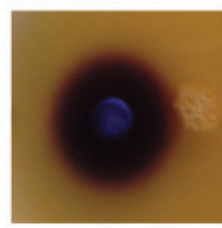

$\mathrm{C}_{6}-\mathrm{HL}$

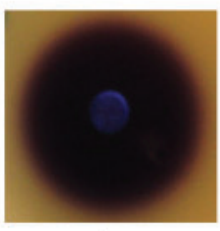

1

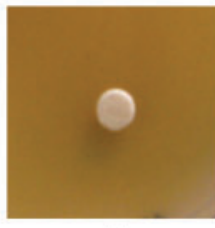

2

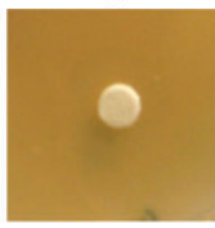

4

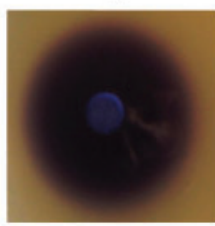

6

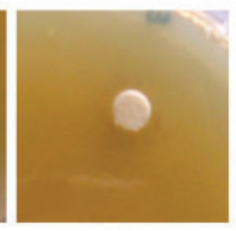

3

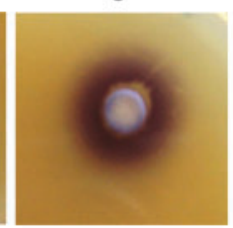

5

(b)

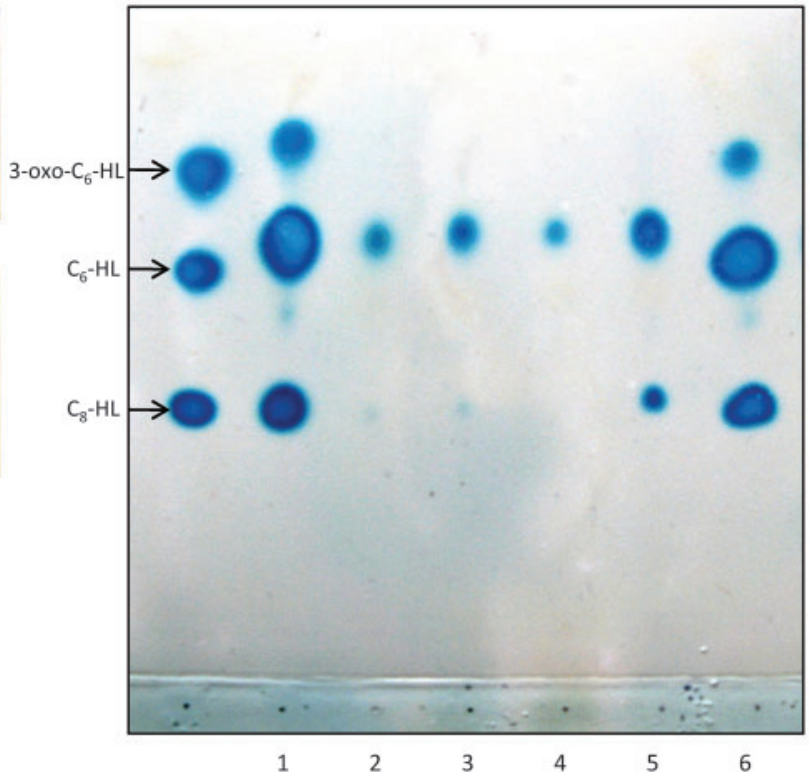

Fig. 1. $A H L$ production in $H$. anticariensis $F P 35^{\top}$ (1), strain FP35-11I (2), strain FP35-11l harbouring pJN-HanR (3), strain FP35hanl (4), strain FP35han/ harbouring pJN-Hanl (5) and strain FP35hanR (6). AHLs extracted from cultures were visualized on an agar plate (a) by means of the C. violaceum CV026 biosensor, and by TLC (b) overlaid with the A. tumefaciens NTL4 (pZLR4) indicator strain. Synthetic AHL compounds were used as references: 3-oxo- $\mathrm{C}_{6}-\mathrm{HL}$ (4.7 pmol); $\mathrm{C}_{6}-\mathrm{HL}$ (80.4 pmol for CV026 and 804 pmol for NTL4); $\mathrm{C}_{8}-\mathrm{HL}$ (31.6 pmol).

start of ORF1. A Southern blot analysis confirmed that a single copy of the transposable element had been integrated into the chromosome of this mutant (data not shown).

The results of a homology search for the nucleotide sequence of the two ORFs in the NCBI database showed 26 to $31 \%$ similarity to the $l u x R$ and $l u x I$ family genes. ORF1, called hanR (for $\underline{H}$. anticariensis $l u x R$ ), contained 759 bp and encoded a putative protein of 252 aa with a predicted molecular mass of $28.9 \mathrm{kDa}$. HanR shared about $31 \%$ identity with LuxR from Burkholderia glumae (Devescovi et al., 2007) and $30 \%$ identity with PhzR from Pseudomonas chlororaphis strain 30-84 (Khan et al., 2007). Genetic and biochemical studies have identified two conserved domains in LuxR-type proteins: the autoinducer-binding N-terminal domain and the DNA-binding C-terminal domain (Whitehead et al., 2001). Analysis of the putative protein HanR in $H$. anticariensis $\mathrm{FP}_{3} 5^{\mathrm{T}}$ with the SMART program revealed that it contained both domains: an autoinducerbinding domain (amino acids 30-178) and a DNA-binding domain with a helix-turn-helix motif, which is characteristic of the LuxR family (amino acids 189-246) (Letunic et al., 2006) (Supplementary Fig. S1). The second ORF, named hanI (for $H$. anticariensis luxI), was located downstream of hanR and was transcribed in the same direction (Fig. 2a). The hanI gene ( $645 \mathrm{bp}$ ) encoded a $24.4 \mathrm{kDa}$ protein homologous to members of the LuxI family of proteins, which are responsible for AHL synthesis. HanI shared $27 \%$ identity with ExpI from Erwinia carotovora (Pirhonen et al., 1993) and $26 \%$ identity with EanI from Pantoea ananatis (Morohoshi et al., 2007). The HanI protein has similar conserved amino acids at the $\mathrm{N}$ terminus to those found in other related AHL synthases (Supplementary Fig. S1).

The quorum-sensing hanR and hanI genes identified are organized in tandem. A similar genetic arrangement has recently been reported in other micro-organisms, such as $R$. palustris (Schaefer et al., 2008), Gluconacetobacter intermedius (Iida et al., 2008), Pseudomonas corrugata (Licciardello et al., 2007), Mesorhizobium tianshanense (Zheng et al., 2006) and Burkholderia cenocepacia (Malott et al., 2005). Nevertheless, in other bacteria, such as Alivivibrio fischeri (Urbanczyk et al., 2007) (formerly Vibrio fischeri), the luxI and luxR genes are transcribed divergently (Engebrecht \& Silverman, 1984).

\section{The hanRI genes are co-transcribed}

Given that the hanR and the hanI genes are aligned in the same direction and only $76 \mathrm{bp}$ of intergenic region separates them (Fig. 2a), they may well constitute an operon. To ascertain whether these two genes were part of the same transcriptional unit we carried out RT-PCR analysis using primers based on their intergenic region sequence. Fig. 2(b) shows the predicted fragment corresponding to the intergenic region.

Two possible $\sigma^{70}$ promoters were identified upstream of the hanR and hanI regions (Fig. 2c) using the promoter 


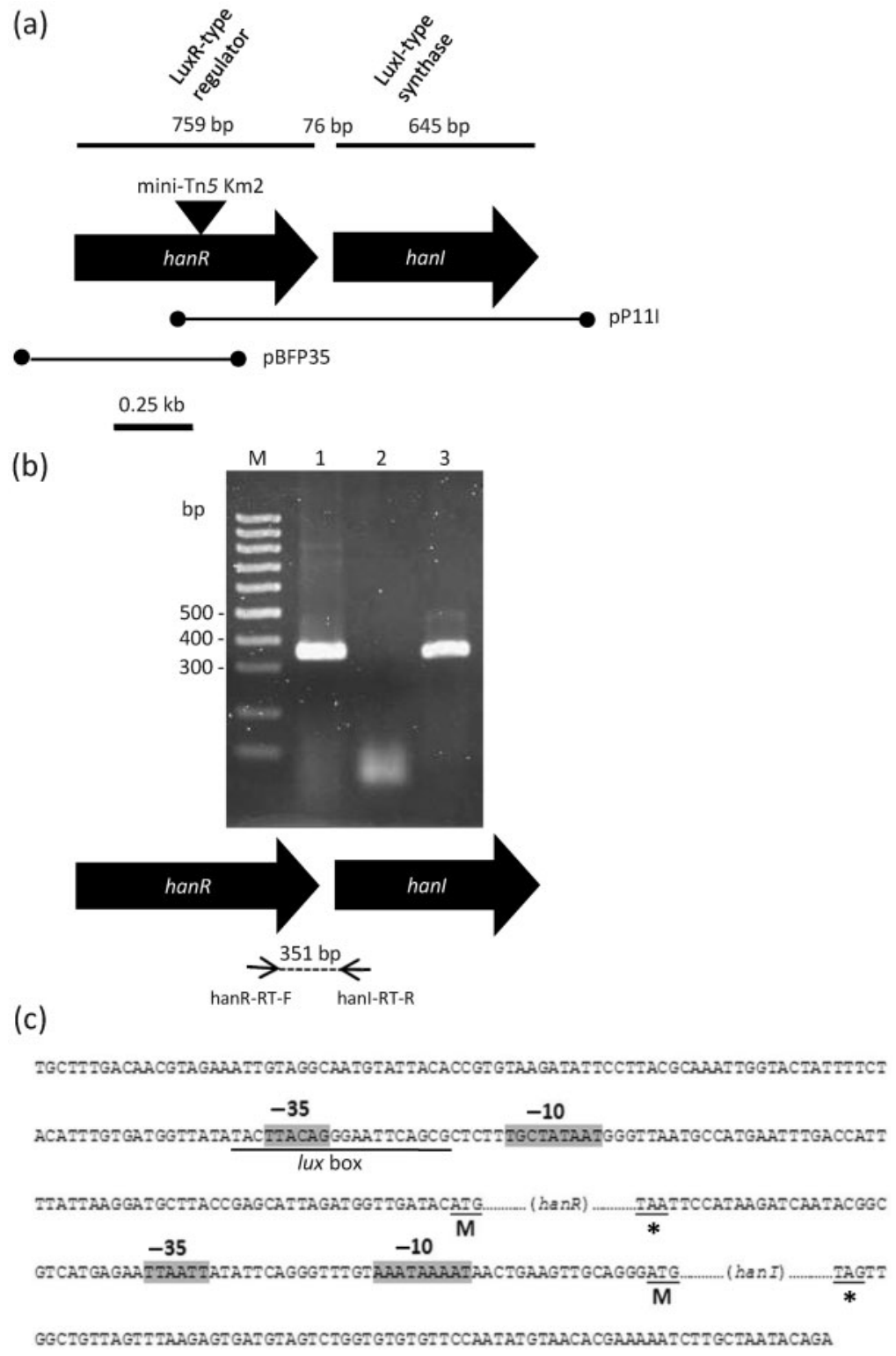

Fig. 2. Transcriptional organization of the hanR/ hanl locus of $H$. anticariensis $\mathrm{FP}^{\top}{ }^{\top}$. (a) Schematic drawing of the hanR and han/ genetic arrangements in $H$. anticariensis $\mathrm{FP} 5^{\top}$. Arrows indicate the proposed direction of transcription. Plasmids used for DNA sequencing, $\mathrm{pP} 11 \mathrm{l}$ and pBFP35, containing Pstl and BamHI restriction fragments, are indicated on the physical map. The mini-Tn5 Km2 transposon insertion site is indicated by a black triangle. (b) Transcriptional analysis of the hanR-hanl intergenic region by RT-PCR. Lanes: M, molecular mass marker (100 bp-1 kb); 1, amplification of DNA sample (positive control); 2, amplification of RNA sample without reverse transcriptase (negative control); 3 , amplification of RNA sample using reverse transcriptase (expected size of the product, $351 \mathrm{bp})$. The location of the primers and span of the intergenic region used in the RT-PCR experiment are shown. (c) Sequence of the DNA region upstream of hanR and hanl, showing the start codon (M) and stop codon (asterisk). A putative lux box-like sequence is present in the region upstream of the hanR gene.

prediction software BPROM. We then constructed fusions of the putative promoter regions of each gene to a 'lacZ gene in the low-copy-number pMP220 vector and transferred it into $H$. anticariensis (see Methods and Table 1). In both cases, promoter activity was detected and measured by $\beta$ galactosidase assays: the FP35(pMP-phanR) strain gave a value of $451.49 \pm 21.61$ Miller units, whereas the FP35 (pMP-phanI) strain gave a value of $72.40 \pm 8.21$ Miller units [the FP35(pMP220) strain gave a value of $6.94 \pm 0.98$ Miller units]. Thus our results suggest that the hanR and hanI genes constitute the same transcriptional unit, although there are promoter activities upstream of each gene.

A putative lux box-like sequence, a $20 \mathrm{bp}$ inverted repeat sequence, was found between positions -78 and -98 upstream of the hanR start translational site (Fig. 2c). This sequence is homologous to other known lux box sequences (Supplementary Table S2). The lux box sequences are thought to represent binding sites of LuxR homologues (Gray et al., 1994) and are located within the promoter regions of many genes regulated by the quorumsensing system.

\section{The expression of hanRI genes is growth phase- dependent}

In a previous work we demonstrated that the synthesis of AHLs in $H$. anticariensis $\mathrm{FP} 35^{\mathrm{T}}$ is growth phase-dependent and that maximum production is reached during the late exponential to stationary phases (Llamas et al., 2005). The relative expression of the hanR and hanI genes, which was measured by using RT-qPCR, increased 83.6- and 45.1fold, respectively, by the end of the exponential growth phase. This finding was to be expected and it confirms that 
the expression of the hanR/hanI system is cell densitydependent, as it is in most quorum-sensing systems (González \& Marketon, 2003).

\section{hanl gene function}

AHL production by the FP35hanI mutant was revealed on an agar plate (Fig. 1a, panel 4) and its pattern was analysed by TLC (Fig. 1b, lane 4), which indicated that it did not produce any detectable levels of AHLs. The slight induction of the NTL4 (pZLR4) indicator strain corresponding to this strain, as shown by TLC, is the same as the signal obtained from a sample prepared from $5 \mathrm{ml}$ uninoculated MY broth medium (Llamas et al., 2005). Therefore, according to these results, HanI would seem to be the sole autoinducer synthase responsible for the production of AHLs in $H$. anticariensis $\mathrm{FP}^{2} 5^{\mathrm{T}}$. The fact that $H$. anticariensis produces at least four different AHLs is not surprising, as the same has been reported in other bacteria such as $M$. tianshanense (Zheng et al., 2006). It has been suggested that the variability in the acyl chain length of AHLs is not only a function of acyl chain specificity but may also be influenced by the cellular pool of acyl ACPs available (Watson et al., 2002). Moreover, AHL production was almost completely restored in the FP35hanI mutant when it was complemented with the hanI gene cloned into the pJN105 expression vector (Fig. 1a, panel 5 and b, lane 5). Although the pJN105 plasmid is a broad-host-range expression vector, it has not been used before in studies with moderate halophiles and so it may be that AHLs were not fully produced because the vector was not properly expressed.

The transcription of hanI synthase from the hanI promoter was measured in the FP35hanI mutant by $\beta$-galactosidase assays, which indicated that it was unaffected by adding exogenous AHLs to the culture (Supplementary Fig. S2). Since we were unable to detect autoinduction in the synthesis of AHLs in $H$. anticariensis $\mathrm{FP} 35^{\mathrm{T}}$, we suggest that the classic A. fischeri autoinduction of the hanI gene does not take place in this strain in the same way as has been described in other bacteria (Andersson et al., 2000; Christensen et al., 2003; Nasser et al., 1998; Throup et al., 1995). Moreover, No lux box-like regulatory element could be identified within the region upstream of the translational start codon of the hanI gene.

\section{hanR gene function}

The FP35hanR mutant produced quantities of signal molecules similar to those of the wild-type (Fig. 1a, panel 6 and $\mathrm{b}$, lane 6). This result was unexpected, since the majority of $\operatorname{luxR}$ mutants described in other bacteria produce fewer or no AHLs. Since the FP35hanR mutant was completely defective in hanR expression (Supplementary Fig. S3a) and the level of expression of the hanI gene was similar to that of the wild-type strain (Supplementary Fig. S3a), it would seem that the HanR protein is not essential for AHL production in H. anticariensis $\mathrm{FP} 35^{\mathrm{T}}$.
In contrast, the FP35hanR mutant synthesized higher quantities of AHLs than FP35-11I (mini-Tn5: : hanR) (Fig. $1 \mathrm{~b}$, lanes 2 and 6), another mutant in which the hanR gene is not transcribed (Supplementary Fig. S3a). This result may well be due to a polar effect caused by the transposon on the hanI gene downstream, since the hanI gene expression level is lower than that of $\mathrm{FP}^{2} 5^{\mathrm{T}}$ or $\mathrm{FP} 35$ han $R$ (Supplementary Fig. S3a). In fact, AHL production was not restored in the FP35-11I mutant when it was complemented with the pJN-HanR plasmid (Fig. 1a, panel 3 and b, lane 3).

The presence of a putative lux box-like sequence upstream of the hanR start codon suggested that the expression of hanR was AHL-dependent. Nevertheless, we found that transcription of the han $R$ gene was induced in the AHLdeficient strain FP35hanI to a degree similar to that of the wild-type strain even when crude extracts of AHLs were added to the bacterial culture (Supplementary Fig. S3b). This result suggests that hanR is expressed from its own promoter but does not seem to be modulated by the AHL signalling molecules under our assay conditions. One explanation is that HanR might have the capacity to act as a regulator of its own expression even without binding to the AHLs. Another explanation is that there might be one or more additional transcriptional LuxR regulators in $H$. anticariensis $\mathrm{FP} 35^{\mathrm{T}}$. These unpaired LuxR family proteins have been well characterized and shown to be integrated with the resident complete AHL quorum-sensing regulatory network (Patankar \& González, 2009; Subramoni \& Venturi, 2009). This has been reported in the SinRI quorum-sensing system of Sinorhizobium meliloti, where the ExpR regulator, an unpaired LuxR homologue, binds to a site in the $\sin R-\sin I$ intergenic region, which affects the transcription of the sinI synthase gene (Hoang et al., 2004; McIntosh et al., 2009). More studies must be undertaken in H. anticarisensis $\mathrm{FP} 35^{\mathrm{T}}$ to test these hypotheses.

Having identified and characterized the quorum-sensing hanR/hanI system involved in the synthesis of AHLs in $H$. anticariensis $\mathrm{FP} 35^{\mathrm{T}}$, we are now turning our attention to the role of this type of cell density-dependent gene regulation in the extreme environments in which Halomonas species live and in which they are ubiquitous. Within this context, Halomonas species are in general considered to be free-living bacteria, and many of them produce exopolysaccharides that allow them to form biofilms; cell-to-cell communication may then be necessary to regulate the bacterial community in any given niche. To our knowledge this is the first report describing genetically the quorum-sensing system in a moderately halophilic bacterium, and it confirms previous evidence for cell-tocell communication amongst micro-organisms in an extreme environment (Llamas et al., 2005).

\section{ACKNOWLEDGEMENTS}

This research was supported by grants from the Spanish Ministerio de Educación y Ciencia (CGL2008-02399/BOS; AGL2009-07656), the 
Consejería de Educación Ciencia y Empresa, of the Andalucian Regional Government (P06-CVI-01850) and from the Plan Andaluz de Investigación. We thank Dr Nuria Ferrol for her help with the realtime PCR assays. We also thank Dr Berenguer's laboratory for their helpful discussions and critical reading of the manuscript. We thank our colleague Dr J. Trout for revising our English text. A. T. was supported by a postgraduate grant from the Junta de Andalucía.

\section{REFERENCES}

Andersson, R. A., Eriksson, A. R., Heikinheimo, R., Mäe, A., Pirhonen, M., Kõiv, V., Hyytiäinen, H., Tuikkala, A. \& Palva, E. T. (2000). Quorum sensing in the plant pathogen Erwinia carotovora subsp. carotovora: the role of $\exp R(E c c)$. Mol Plant Microbe Interact 13, 384393.

Boyer, M. \& Wisniewski-Dyé, F. (2009). Cell-cell signalling in bacteria: not simply a matter of quorum. FEMS Microbiol Ecol 70, $1-19$.

Chen, X., Schauder, S., Potier, N., Van Dorsselaer, A., Pelczer, I., Bassler, B. L. \& Hughson, F. M. (2002). Structural identification of a bacterial quorum-sensing signal containing boron. Nature 415, 545549.

Christensen, A. B., Riedel, K., Eberl, L., Flodgaard, L. R., Molin, S. Gram, L. \& Givskov, M. (2003). Quorum-sensing-directed protein expression in Serratia proteamaculans B5a. Microbiology 149, 471-483.

Davies, D. G., Parsek, M. R., Pearson, J. P., Iglewski, B. H., Costerton, J. W. \& Greenberg, E. P. (1998). The involvement of cell-to-cell signals in the development of a bacterial biofilm. Science 280, 295298.

de Kievit, T. R. \& Iglewski, B. H. (2000). Bacterial quorum sensing in pathogenic relationships. Infect Immun 68, 4839-4849.

de Lorenzo, V., Herrero, M., Jakubzik, U. \& Timmis, K. N. (1990). Mini-Tn 5 transposon derivatives for insertion mutagenesis, promoter probing, and chromosomal insertion of cloned DNA in Gramnegative eubacteria. J Bacteriol 172, 6568-6572.

Defoirdt, T., Boon, N., Sorgeloos, P., Verstraete, W. \& Bossier, P. (2008). Quorum sensing and quorum quenching in Vibrio harveyi: lessons learned from in vivo work. ISME J 2, 19-26.

Devescovi, G., Bigirimana, J., Degrassi, G., Cabrio, L., LiPuma, J. J., Kim, J., Hwang, I. \& Venturi, V. (2007). Involvement of a quorumsensing-regulated lipase secreted by a clinical isolate of Burkholderia glumae in severe disease symptoms in rice. Appl Environ Microbiol 73, 4950-4958.

Diggle, S. P., Griffin, A. S., Campbell, G. S. \& West, S. A. (2007) Cooperation and conflict in quorum-sensing bacterial populations. Nature 450, 411-414

Eberhard, A., Longin, T., Widrig, C. A. \& Stranick, S. J. (1991). Synthesis of the lux gene autoinducer in Vibrio fischeri is positively autoregulated. Arch Microbiol 155, 294-297.

Engebrecht, J. \& Silverman, M. (1984). Identification of genes and gene products necessary for bacterial bioluminescence. Proc Natl Acad Sci U S A 81, 4154-4158.

Euzéby, J. P. (2010). List of Prokaryotic Names with Standing in Nomenclature. http://www.bacterio.cict.fr

Farrand, S. K. (1998). Conjugation in Rhizobiaceae. In The Rhizobiaceae, Molecular Biology of Model Plant-Associated Bacteria, pp. 199-233. Edited by H. P. Spaink, A. Kondorosi \& P. J. J. Hooykaas. Dordrecht: Kluwer Academic.

Fuqua, W. C., Winans, S. C. \& Greenberg, E. P. (1994). Quorum sensing in bacteria: the LuxR-LuxI family of cell density-responsive transcriptional regulators. J Bacteriol 176, 269-275.
Fuqua, C., Parsek, M. R. \& Greenberg, E. P. (2001). Regulation of gene expression by cell-to-cell communication: acyl-homoserine lactone quorum sensing. Annu Rev Genet 35, 439-468.

González, J. E. \& Keshavan, N. D. (2006). Messing with bacterial quorum sensing. Microbiol Mol Biol Rev 70, 859-875.

González, J. E. \& Marketon, M. M. (2003). Quorum sensing in nitrogen-fixing rhizobia. Microbiol Mol Biol Rev 67, 574-592.

Gray, K. M., Passador, L., Iglewski, B. H. \& Greenberg, E. P. (1994). Interchangeability and specificity of components from the quorumsensing regulatory systems of Vibrio fischeri and Pseudomonas aeruginosa. J Bacteriol 176, 3076-3080.

Hoang, H. H., Becker, A. \& González, J. E. (2004). The LuxR homolog ExpR, in combination with the Sin quorum sensing system, plays a central role in Sinorhizobium meliloti gene expression. J Bacteriol 186, 5460-5472.

Horng, Y. T., Deng, S. C., Daykin, M., Soo, P. C., Wei, J. R., Luh, K. T., Ho, S. W., Swift, S., Lai, H. C. \& Williams, P. (2002). The LuxR family protein $\mathrm{SpnR}$ functions as a negative regulator of $\mathrm{N}$-acylhomoserine lactone-dependent quorum sensing in Serratia marcescens. Mol Microbiol 45, 1655-1671.

lida, A., Ohnishi, Y. \& Horinouchi, S. (2008). Control of acetic acid fermentation by quorum sensing via $\mathrm{N}$-acylhomoserine lactones in Gluconacetobacter intermedius. J Bacteriol 190, 2546-2555.

Kalogeraki, V. S. \& Winans, S. C. (1997). Suicide plasmids containing promoterless reporter genes can simultaneously disrupt and create fusions to target genes of diverse bacteria. Gene 188, 69-75.

Khan, S. R., Herman, J., Krank, J., Serkova, N. J., Churchill, M. E. A., Suga, H. \& Farrand, S. K. (2007). N-(3-hydroxyhexanoyl)-Lhomoserine lactone is the biologically relevant quormone that regulates the phz operon of Pseudomonas chlororaphis strain 30-84. Appl Environ Microbiol 73, 7443-7455.

Letunic, I., Copley, R. R., Pils, B., Pinkert, S., Schultz, J. \& Bork, P. (2006). SMART 5: domains in the context of genomes and networks. Nucleic Acids Res 34 (Database issue), D257-D260.

Licciardello, G., Bertani, I., Steindler, L., Bella, P., Venturi, V. \& Catara, V. (2007). Pseudomonas corrugata contains a conserved $\mathrm{N}$-acyl homoserine lactone quorum sensing system; its role in tomato pathogenicity and tobacco hypersensitivity response. FEMS Microbiol Ecol 61, 222-234.

Llamas, I., del Moral, A., Béjar, V., Girón, M. D., Salto, R. \& Quesada, E. (1997). Plasmids from Halomonas eurihalina, a microorganism which produces an exopolysaccharide of biotechnological interest. FEMS Microbiol Lett 156, 251-257.

Llamas, I., Argandoña, M., Quesada, E. \& del Moral, A. (2000). Transposon mutagenesis in Halomonas eurihalina. Res Microbiol 151, $13-18$.

Llamas, I., Suárez, A., Quesada, E., Béjar, V. \& del Moral, A. (2003). Identification and characterization of the $c a r A B$ genes responsible for encoding carbamoylphosphate synthetase in Halomonas eurihalina. Extremophiles 7, 205-211.

Llamas, I., Keshavan, N. \& González, J. E. (2004). Use of Sinorhizobium meliloti as an indicator for specific detection of longchain $\mathrm{N}$-acyl homoserine lactones. Appl Environ Microbiol 70, 37153723.

Llamas, I., Quesada, E., Martínez-Cánovas, M. J., Gronquist, M., Eberhard, A. \& González, J. E. (2005). Quorum sensing in halophilic bacteria: detection of $\mathrm{N}$-acyl-homoserine lactones in the exopolysaccharide-producing species of Halomonas. Extremophiles 9, 333-341.

Malott, R. J., Baldwin, A., Mahenthiralingam, E. \& Sokol, P. A. (2005). Characterization of the cciIR quorum-sensing system in Burkholderia cenocepacia. Infect Immun 73, 4982-4992. 
Marketon, M. M. \& González, J. E. (2002). Identification of two quorum-sensing systems in Sinorhizobium meliloti. J Bacteriol 184, 3466-3475.

Marketon, M. M., Gronquist, M. R., Eberhard, A. \& González, J. E. (2002). Characterization of the Sinorhizobium meliloti $\sin R / \operatorname{sinI}$ locus and the production of novel $\mathrm{N}$-acyl homoserine lactones. J Bacteriol 184, 5686-5695.

Marketon, M. M., Glenn, S. A., Eberhard, A. \& González, J. E. (2003). Quorum sensing controls exopolysaccharide production in Sinorhizobium meliloti. J Bacteriol 185, 325-331.

Martínez-Cánovas, M. J., Béjar, V., Martínez-Checa, F. \& Quesada, E. (2004). Halomonas anticariensis sp. nov., from Fuente de Piedra, a saline-wetland wildfowl reserve in Malaga, southern Spain. Int J Syst Evol Microbiol 54, 1329-1332.

McClean, K. H., Winson, M. K., Fish, L., Taylor, A., Chhabra, S. R., Camara, M., Daykin, M., Lamb, J. H., Swift, S. \& other authors (1997). Quorum sensing and Chromobacterium violaceum: exploitation of violacein production and inhibition for the detection of $\mathrm{N}$ acylhomoserine lactones. Microbiology 143, 3703-3711.

McIntosh, M., Meyer, S. \& Becker, A. (2009). Novel Sinorhizobium meliloti quorum sensing positive and negative regulatory feedback mechanisms respond to phosphate availability. Mol Microbiol 74, $1238-1256$.

McNab, R., Ford, S. K., El-Sabaeny, A., Barbieri, B., Cook, G. S. \& Lamont, R. J. (2003). LuxS-based signaling in Streptococcus gordonii: autoinducer 2 controls carbohydrate metabolism and biofilm formation with Porphyromonas gingivalis. J Bacteriol 185, 274-284.

Miller, J. (1972). Experiments in Molecular Genetics. Cold Spring Harbor, NY: Cold Spring Harbor Laboratory.

Miller, V. L. \& Mekalanos, J. J. (1988). A novel suicide vector and its use in construction of insertion mutations: osmoregulation of outer membrane proteins and virulence determinants in Vibrio cholerae requires toxR. J Bacteriol 170, 2575-2583.

Moraine, R. A. \& Rogovin, P. (1966). Kinetics of polysaccharide B1459 fermentation. Biotechnol Bioeng 8, 511-524.

Morohoshi, T., Nakamura, Y., Yamazaki, G., Ishida, A., Kato, N. \& Ikeda, T. (2007). The plant pathogen Pantoea ananatis produces $N$ acylhomoserine lactone and causes center rot disease of onion by quorum sensing. J Bacteriol 189, 8333-8338.

Nasser, W., Bouillant, M. L., Salmond, G. \& Reverchon, S. (1998). Characterization of the Erwinia chrysanthemi $\exp I-\operatorname{expR}$ locus directing the synthesis of two $\mathrm{N}$-acyl-homoserine lactone signal molecules. Mol Microbiol 29, 1391-1405.

Newman, J. R. \& Fuqua, C. (1999). Broad-host-range expression vectors that carry the L-arabinose-inducible Escherichia coli araBAD promoter and the araC regulator. Gene 227, 197-203.

Ng, W. L. \& Bassler, B. L. (2009). Bacterial quorum-sensing network architectures. Annu Rev Genet 43, 197-222.

Nieto, J. J., Fernández-Castillo, R., Márquez, M. C., Ventosa, A., Quesada, E. \& Ruiz-Berraquero, F. (1989). Survey of metal tolerance in moderately halophilic eubacteria. Appl Environ Microbiol 55, 23852390.

Niu, C., Clemmer, K. M., Bonomo, R. A. \& Rather, P. N. (2008). Isolation and characterization of an autoinducer synthase from Acinetobacter baumannii. J Bacteriol 190, 3386-3392.

Ochman, H., Gerber, A. S. \& Hartl, D. L. (1988). Genetic applications of an inverse polymerase chain reaction. Genetics 120, 621-623.

Parker, C. T. \& Sperandio, V. (2009). Cell-to-cell signalling during pathogenesis. Cell Microbiol 11, 363-369.

Patankar, A. V. \& González, J. E. (2009). Orphan LuxR regulators of quorum sensing. FEMS Microbiol Rev 33, 739-756.
Pfaffl, M. W., Horgan, G. W. \& Dempfle, L. (2002). Relative expression software tool (REST) for group-wise comparison and statistical analysis of relative expression results in real-time PCR. Nucleic Acids Res 30, e36.

Pirhonen, M., Flego, D., Heikinheimo, R. \& Palva, E. T. (1993). A small diffusible signal molecule is responsible for the global control of virulence and exoenzyme production in the plant pathogen Erwinia carotovora. EMBO J 12, 2467-2476.

Pumbwe, L., Skilbeck, C. A. \& Wexler, H. M. (2008). Presence of quorum-sensing systems associated with multidrug resistance and biofilm formation in Bacteroides fragilis. Microb Ecol 56, 412-419.

Rodríguez-Valera, F., Ruíz-Berraquero, F. \& Ramos-Cormenzana, A. (1981). Characteristics of the heterotrophic bacterial populations in hypersaline environments of different salt concentrations. Microb Ecol 7, 235-243.

Sambrook, J. \& Russell, D. W. (2001). Molecular Cloning: a Laboratory Manual. Cold Spring Harbor, NY: Cold Spring Harbor Laboratory.

Schaefer, A. L., Greenberg, E. P., Oliver, C. M., Oda, Y., Huang, J. J., Bittan-Banin, G., Peres, C. M., Schmidt, S., Juhaszova, K. \& other authors (2008). A new class of homoserine lactone quorum-sensing signals. Nature 454, 595-599.

Shaw, P. D., Ping, G., Daly, S. L., Cha, C., Cronan, J. E., Jr, Rinehart, K. L. \& Farrand, S. K. (1997). Detecting and characterizing $N$-acylhomoserine lactone signal molecules by thin-layer chromatography. Proc Natl Acad Sci U S A 94, 6036-6041.

Song, Y., Xie, C., Ong, Y.-M., Gan, Y.-H. \& Chua, K.-L. (2005). The BpsIR quorum-sensing system of Burkholderia pseudomallei. J Bacteriol 187, 785-790.

Spaink, H. P., Wijffelman, C. A., Pees, E., Okker, R. J. H. \& Lugtenberg, B. J. J. (1987). Rhizobium nodulation gene nodD as a determinant of host specificity. Nature 328, 337-340.

Subramoni, S. \& Venturi, V. (2009). LuxR-family 'solos': bachelor sensors/regulators of signalling molecules. Microbiology 155, 1377-1385.

Sutherland, I. W. (2002). Polysaccharides from prokaryotes. In Biopolymers. Polysaccharides I, pp. 1-19. Edited by E. J. Vandamme, S. De Baets \& A. Steinbüchel. Weinheim: Wiley-VCH.

Taga, M. E. \& Bassler, B. L. (2003). Chemical communication among bacteria. Proc Natl Acad Sci U S A 100 (Suppl 2), 14549-14554.

Throup, J. P., Cámara, M., Briggs, G., Winson, M. K., Bycroft, B. W., Williams, P. \& Stewart, G. S. (1995). Characterisation of the yenI/ yenR locus from Yersinia enterocolitica mediating the synthesis of two $\mathrm{N}$-acylhomoserine lactone signal molecules. Mol Microbiol 17, 345-356.

Urbanczyk, H., Ast, J. C., Higgins, M. J., Carson, J. \& Dunlap, P. V. (2007). Reclassification of Vibrio fischeri, Vibrio logei, Vibrio salmonicida and Vibrio wodanis as Aliivibrio fischeri gen. nov., comb. nov., Aliivibrio logei comb. nov., Aliivibrio salmonicida comb. nov. and Alivibrio wodanis comb. nov. Int J Syst Evol Microbiol 57, 2823 2829.

Van Houdt, R., Moons, P., Aertsen, A., Jansen, A., Vanoirbeek, K., Daykin, M., Williams, P. \& Michiels, C. W. (2007). Characterization of a luxI/luxR-type quorum sensing system and $N$-acyl-homoserine lactone-dependent regulation of exo-enzyme and antibacterial component production in Serratia plymuthica RVH1. Res Microbiol 158, 150-158.

von Bodman, S. B., Majerczak, D. R. \& Coplin, D. L. (1998). A negative regulator mediates quorum-sensing control of exopolysaccharide production in Pantoea stewartii subsp. stewartii. Proc Natl Acad Sci U S A 95, 7687-7692.

von Bodman, S. B., Bauer, W. D. \& Coplin, D. L. (2003). Quorum sensing in plant-pathogenic bacteria. Annu Rev Phytopathol 41, 455482. 
Wang, L. H., He, Y., Gao, Y., Wu, J. E., Dong, Y. H., He, C., Wang, S. X., Weng, L. X., Xu, J. L. \& other authors (2004). A bacterial cell-cell communication signal with cross-kingdom structural analogues. Mol Microbiol 51, 903-912.

Watson, W. T., Minogue, T. D., Val, D. L., von Bodman, S. B. \& Churchill, M. E. (2002). Structural basis and specificity of acylhomoserine lactone signal production in bacterial quorum sensing. Mol Cell 9, 685-694.

Whitehead, N. A., Barnard, A. M., Slater, H., Simpson, N. J. \& Salmond, G. P. (2001). Quorum-sensing in Gram-negative bacteria. FEMS Microbiol Rev 25, 365-404.
Winson, M. K., Swift, S., Fish, L., Throup, J. P., Jørgensen, F., Chhabra, S. R., Bycroft, B. W., Williams, P. \& Stewart, G. S. (1998). Construction and analysis of luxCDABE-based plasmid sensors for investigating $N$-acyl homoserine lactone-mediated quorum sensing. FEMS Microbiol Lett 163, 185-192.

Zheng, H., Zhong, Z., Lai, X., Chen, W.-X., Li, S. \& Zhu, J. (2006). A LuxR/LuxI-type quorum-sensing system in a plant bacterium, Mesorhizobium tianshanense, controls symbiotic nodulation. J Bacteriol 188, 1943-1949.

Edited by: D. Demuth 